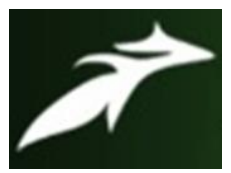

Milufarzana et al, International Journal of Advances in Agricultural Science and Technology,

Vol.8 Issue.9, September-2021, pg. 41-51

ISSN: $2348-1358$

Impact Factor: 6.057

NAAS Rating: 3.77

\title{
PRESENT STATUS OF AGRICULTURAL MECHANIZATION: A STUDY ON THREE UPAZILAS OF PANCHAGARH DISTRICT IN BANGLADESH
}

\author{
Milufarzana $^{1 *}$; Hasna Hena Prianka ${ }^{2}$; Selina Banu ${ }^{3}$; Maisha Fahmida ${ }^{4}$; Farha Anjum Tapu ${ }^{5}$ \\ ${ }^{1}$ Assistant Professor, Department of Agricultural and Industrial Engineering, Hajee Mohammad Danesh Science and \\ Technology University, Dinajpur, Bangladesh, E-mail: milu.bau@gmail.com \\ ${ }^{2}$ Post Graduate Student, Department of Agricultural and Industrial Engineering, Hajee Mohammad Danesh Science \\ and Technology University, Dinajpur, Bangladesh, E-mail: prinkareza2017@gmail.com \\ ${ }^{3}$ Assistant Professor, Department of Agricultural and Industrial Engineering, Hajee Mohammad Danesh Science and \\ Technology University, Dinajpur, Bangladesh, E-mail: Selina.nit@gmail.com \\ ${ }^{4}$ Assistant Professor, Department of Agricultural and Industrial Engineering, Hajee Mohammad Danesh Science and \\ Technology University, Dinajpur, Bangladesh, E-mail: maisha.fahmida@hstu.ac.bd \\ ${ }^{5}$ Lecturer, Department of Agricultural and Industrial Engineering, Hajee Mohammad Danesh Science and \\ Technology University, Dinajpur, Bangladesh, E-mail: farhaanjum280@gmai.com
}

DOI: 10.47856/ijaast.2021.v08i9.006

\begin{abstract}
Nowadays in Bangladesh, farm mechanization is one of the major cause of change in agricultural sector. Due to labor shortage and high wage rate of labor, farmers are compelled to accept farm mechanization. The purpose of the study was to assess the modern agricultural technologies used in Panchagarh district and develop statistical information. The study period was from August 2019 to October 2019. For this study, three places such as Panchagarh Sadar, Boda and Debiganj were selected. Present status was analyzed based on irrigation management system, tillage practices, insect control practices, harvesting and post-harvesting operation, drying and storage facilities for rice production. A structured questionnaire was used to collect the information's of machinery used in selected places. The study revealed that irrigation, land preparation and crop protection was almost mechanized, but mechanization is still lacking in harvesting operation. There were no transplanter, seed drill and fertilizer applicator found in the study areas used by farmers. Crops were still dried through sun drying storage was done by the traditional storage technologies. It is a fact that mechanization is in progress in these areas but need more extension work with modern machineries. The government should develop proper planning by investigating present status of mechanization and improve the present condition by increasing machinery utilization.
\end{abstract}

Keywords: Agriculture, Mechanization, Present Status, Modern Machinery, Panchagarh District.

\section{Introduction}

Agricultural mechanization is the science application of mechanical aids for increased

production, processing and storage of food with less drudgery and increased efficiency (Esmay\&

Hall, 1972). 


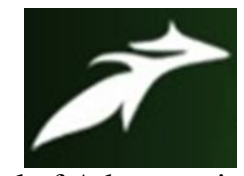

Milufarzana et al, International Journal of Advances in Agricultural Science and Technology,

Vol.8 Issue.9, September-2021, pg. 41-51

ISSN: $2348-1358$

Impact Factor: 6.057

NAAS Rating: 3.77

The population of Bangladesh is increasing day by day and horizontal expansion of cultivated area is not possible due to high population pressure. Total rice production in Bangladesh was about 10.97 million tons in the year 1971 when the country's population was about 70.88 million. At present, the country is now producing about 36.3 million tons to feed her 168.19 million people (BBS, 2018). Population growth rate in Bangladesh is two million people per year and the population will reach 233.2 million by 2050 , going by the current trend (BBS, 2012). Bangladesh will require more than 55.0 million tons of rice per year to feed its people by the year 2050. Bangladesh will require about 31.3 to 42.0 million tons of rice for the year 2030 (IFPRI, 2012). During this time total rice area will also shrink to 10.68 million hectares. Therefore, it is an urgent need of the time to use modern technologies for increasing the yield of rice.

Contribution of agriculture sector in GDP of Bangladesh is gradually declining. GDP growth was 44\% during 1971 - 1980 and it fell $13.82 \%$ in to 2018-2019 Fiscal Year. According to the Bangladesh Economic Survey and World Bank statistics, the contribution of agriculture to GDP growth has been declining day by day.

At present about $85 \%$ of land preparation is done mainly by power tillers and to some extent by tractors (BBS, 2017). The present cropping intensity of $194 \%$ could not have been achieved without mechanization of tillage operation. As pedal thresher proved inadequate to thresh bulk production of rice, power threshers have been developed and it is estimated that more than 


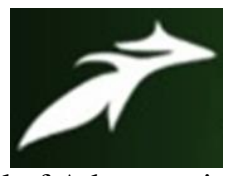

Milufarzana et al, International Journal of Advances in Agricultural Science and Technology,

Vol.8 Issue.9, September-2021, pg. 41-51

ISSN: $2348-1358$

Impact Factor: 6.057

NAAS Rating: 3.77

60,000 are in use in the country. However, threshing of maize is accomplished almost $100 \%$ by power and hand maize shellers.

Mechanization is an important tool for profitable and competitive agriculture. The need for mechanization is increasing fast with the decrease of draft power. Without mechanization it will not be possible to maintain multiple cropping patterns, which need quick land preparation, planting, weeding, harvesting, processing etc. (MoA, 2009).

The total area of Panchagarh district is $1404.62 \mathrm{sq} \mathrm{km}$, the population is total 836196. Main sources of income is agriculture $70.96 \%$, non-agricultural labourer $5.42 \%$, industry $0.47 \%$, commerce 9.6\% (BD population cencus, 2001). The economy of Panchagarh is predominantly agro based. According to Census of Agriculture 2008 total holdings are 203,831. Among 203,831 holdings of the district, $68.12 \%$ holding are farms that produce varieties of crops, namely local and HYV paddy, wheat, jute, vegetables, spices, pulses, oilseeds, sugarcane and others.

Employment agriculture meets the demand of increasing food requirement and raw materials for the manufacturing units. Mechanization of this sector implies the use of various power sources and improved farm tools and equipment, with a view to reduce the drudgery of the human beings and draught animals. Application of farm mechanization will adversely affect the labour requirement, which will adversely affect the exiting unemployment situation. The choice of agricultural mechanization analysis is determined by two considerations. First employment 


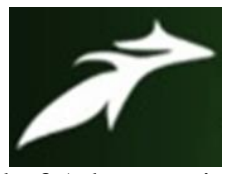

Milufarzana et al, International Journal of Advances in Agricultural Science and Technology,

Vol.8 Issue.9, September-2021, pg. 41-51

ISSN: 2348-1358

Impact Factor: 6.057

NAAS Rating: 3.77

agriculture is the largest sector in the study areas. And secondly the highest level of mechanization is found the use of various power sources and improved farm tools and equipment to the overall productivity of farming system. Keeping all this factors in consideration the present study was under taken. The objective of this research was to assess the current status of agricultural mechanization in three selected upazilas of Panchagarh District.

\section{Materials and Methods}

Study area and period: To conduct the current research, work three upazilas were selected among 5 of Panchagarh district. From each upazila 3 unions and from each union five villages were selected for the study. Three upazila selected for the survey work were Panchagarh sadar upazila, Boda upazila and Debiganj upazila. Table 1 shows the selected Upazila, Unions and villages for the study. Data were collected from August 2019 to October 2019.

Table 1. List of Upazila, unions and villages selected for the survey work

\begin{tabular}{|c|c|c|}
\hline Upazila & Unions & Villages \\
\hline \multirow{15}{*}{ Panchagarh Sadar } & \multirow{5}{*}{ Dhakkamara } & Kazipara \\
\hline & & Purbo Shikarpur \\
\hline & & Khanpukur \\
\hline & & Araji Shikarpur \\
\hline & & Noilapara \\
\hline & \multirow{5}{*}{ Gorinabari } & Bozrapara \\
\hline & & Goleha \\
\hline & & Notunbosti \\
\hline & & Kashimpur \\
\hline & & Futkibari \\
\hline & \multirow{5}{*}{ Magura } & Kaleshorgao \\
\hline & & Magura sadar \\
\hline & & Majhipara \\
\hline & & Dosmile \\
\hline & & Kazirhat \\
\hline
\end{tabular}




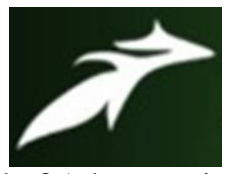

Milufarzana et al, International Journal of Advances in Agricultural Science and Technology,

Vol.8 Issue.9, September-2021, pg. 41-51

ISSN: $2348-1358$

Impact Factor: 6.057

NAAS Rating: 3.77

\begin{tabular}{|c|c|c|}
\hline \multirow{15}{*}{ Boda } & \multirow{5}{*}{ Boda } & Dabordanga \\
\hline & & Shimultoli \\
\hline & & Shibaipara \\
\hline & & Jamadarpara \\
\hline & & Shatkhamar \\
\hline & \multirow{5}{*}{ Chandanbari } & Chandanbari \\
\hline & & Bottoli \\
\hline & & Sarkarpara \\
\hline & & Jorpakuri \\
\hline & & Khansamapara \\
\hline & \multirow{5}{*}{ Maidandighi } & Arajigaighata \\
\hline & & Horipur \\
\hline & & Ragpur \\
\hline & & Shipaipara \\
\hline & & Magurapara \\
\hline \multirow{15}{*}{ Debiganj } & \multirow{5}{*}{ Debiganj } & Prodhanpara \\
\hline & & Notunbandar \\
\hline & & Taltola \\
\hline & & Moholdarpara \\
\hline & & Collagepara \\
\hline & \multirow{5}{*}{ Sonahar } & Bondarpara \\
\hline & & Mostofapur \\
\hline & & Clubganj \\
\hline & & Dhontola \\
\hline & & Mollikadah \\
\hline & \multirow{5}{*}{ Debiduba } & Chaurangi Kalibari \\
\hline & & Peralbari Mistiripara \\
\hline & & Nalarpar \\
\hline & & Khutamara Prodhanpara \\
\hline & & Khutamara Beltolipara \\
\hline
\end{tabular}

Selection of target group and sample size: The target group was farmers. Five villages were selected from each union. Therefore, total 45 villages were surveyed and collected information from 8-10 farmers of each village. 


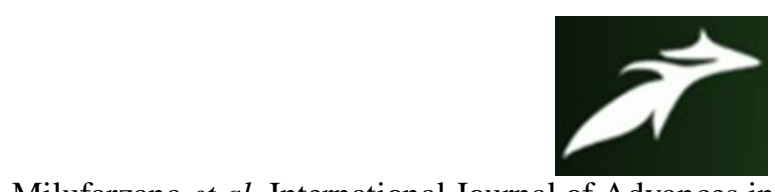

Milufarzana et al, International Journal of Advances in Agricultural Science and Technology,

Vol.8 Issue.9, September-2021, pg. 41-51

ISSN: $2348-1358$

Impact Factor: 6.057

NAAS Rating: 3.77

Preparation of the Questionnaire: In this study, data were collected from a field survey. Before field survey a set of questionnaire was developed based on the objectives and methodologies used for this research. Draft questionnaires have been prepared and pretested, and necessary addition and subtraction has been done accordingly to finalize the questionnaire.

Data Collection: In this study, the interview method was followed to achieve the research objectives, as it is less costly and less time consuming. Data were collected through direct interview with the farmers. Secondary data from various sources such as journals, books, published reports and theses were used in this piece of research.

Processing of Data: The collected data were processed for analysis. Having interviewed a respondent, each schedule was checked and verified so that information on each item has been properly recorded. If any item seemed to be inconsistent or contradictory, the respondents were revisited and the missing information was collected. The data were entered into a computer by using the MS Excel (Microsoft Excel) for analyzing and output generation.

Analytical Techniques: The collected data were complied, tabulated and analyzed in accordance with the objective of the study.

\section{Problem faced in Collecting Data}

During the period of data collection, the researcher faced various problems. Some of the major problems are briefly discussed below.

1. Most of the respondents initially hesitated to answer questions because they had no previous idea about such type of research. 


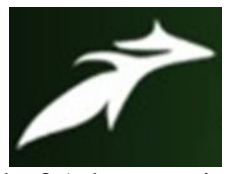

Milufarzana et al, International Journal of Advances in Agricultural Science and Technology,

Vol.8 Issue.9, September-2021, pg. 41-51

ISSN: $2348-1358$

Impact Factor: 6.057

NAAS Rating: 3.77

2. Most of the respondents were afraid of tax imposition or tax increase; they were reluctant to provide information relating to their land holding and other assets. Not only that, some of them asked the researcher whether they would get any benefit from this interviews.

\section{Results and Discussion}

\section{Status of agricultural mechanization in Panchagarh Sadar Upazila}

Table 2 shows use of different machineries and it is evident that number of machines used are not same in three unions. It is seen that use of DTW, STW and power tiller are comparatively more in Gorinabari union than Dhakkamara and Magura union.

Table 2. Machinery used in different selected unions of Panchagarh Sadar Upazila

\begin{tabular}{|c|c|c|c|c|c|c|c|c|c|}
\hline \multirow{2}{*}{$\begin{array}{l}\text { Name of } \\
\text { Unions }\end{array}$} & \multirow{2}{*}{$\begin{array}{l}\text { Name of } \\
\text { Villages }\end{array}$} & \multicolumn{3}{|c|}{ Irrigation Equipment } & \multirow{2}{*}{$\begin{array}{l}\text { Power } \\
\text { tiller } \\
\text { (nos.) }\end{array}$} & \multirow{2}{*}{$\begin{array}{l}\text { Tractor } \\
\text { (nos.) }\end{array}$} & \multirow{2}{*}{$\begin{array}{l}\text { Power } \\
\text { thresher } \\
\text { (nos.) }\end{array}$} & \multirow{2}{*}{$\begin{array}{l}\begin{array}{l}\text { Corn } \\
\text { sheller }\end{array} \\
\text { (nos.) }\end{array}$} & \multirow{2}{*}{$\begin{array}{l}\text { Combined } \\
\text { harvester } \\
\text { (nos.) }\end{array}$} \\
\hline & & $\begin{array}{l}\text { DTW } \\
\text { (nos.) }\end{array}$ & $\begin{array}{l}\text { STW } \\
\text { (nos.) }\end{array}$ & $\begin{array}{l}\text { LLP } \\
\text { (nos.) }\end{array}$ & & & & & \\
\hline & Kazipara & 1 & 6 & 0 & 3 & 2 & 1 & 0 & 0 \\
\hline & Purbo shikarpur & 1 & 6 & 0 & 4 & 2 & 1 & 1 & 0 \\
\hline \multirow[t]{5}{*}{ Dhakkamara } & Khanpukur & 1 & 8 & 1 & 4 & 1 & 2 & 2 & 0 \\
\hline & Araji shikarpur & 0 & 5 & 0 & 3 & 1 & 1 & 0 & 0 \\
\hline & Noilapara & 0 & 7 & 0 & 2 & 2 & 2 & 1 & 0 \\
\hline & Bozrapara & 1 & 6 & 0 & 3 & 2 & 1 & 1 & 0 \\
\hline & Goleha & 0 & 7 & 0 & 5 & 1 & 1 & 0 & 0 \\
\hline \multirow[t]{5}{*}{ Gorinabari } & Notunbosti & 1 & 7 & 0 & 4 & 1 & 1 & 0 & 0 \\
\hline & Kashimpur & 1 & 10 & 1 & 5 & 3 & 2 & 1 & 0 \\
\hline & Futkibari & 1 & 8 & 0 & 3 & 0 & 1 & 1 & 0 \\
\hline & Kaleshorgao & 0 & 7 & 0 & 3 & 1 & 1 & 0 & 0 \\
\hline & Magura Sadar & 1 & 6 & 0 & 4 & 0 & 1 & 1 & 0 \\
\hline \multirow[t]{3}{*}{ Magura } & Majhipara & 0 & 8 & 0 & 4 & 1 & 1 & 1 & 0 \\
\hline & Dosmile & 1 & 8 & 1 & 5 & 2 & 1 & 1 & 1 \\
\hline & Kazirhat & 0 & 5 & 0 & 3 & 2 & 0 & 0 & 0 \\
\hline Total & & 9 & 104 & 3 & 55 & 21 & 17 & 10 & 1 \\
\hline
\end{tabular}

DTW, STW and LLP indicates 9 nos., 104 nos. and 3 nos. respectively. 


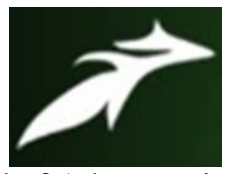

Milufarzana et al, International Journal of Advances in Agricultural Science and Technology,

Vol.8 Issue.9, September-2021, pg. 41-51

ISSN: $2348-1358$

Impact Factor: 6.057

NAAS Rating: 3.77

\section{Status of agricultural mechanization in Boda Upazila}

From Table 3 we can say that, mechanization status in this upazila is good. The table self explains regarding number of machines used in different unions.

Table 3. Machinery used in different selected unions of Boda Upazila

\begin{tabular}{|c|c|c|c|c|c|c|c|c|c|}
\hline \multirow{2}{*}{$\begin{array}{l}\text { Name of } \\
\text { Unions }\end{array}$} & \multirow{2}{*}{$\begin{array}{l}\text { Name of } \\
\text { Villages }\end{array}$} & \multicolumn{3}{|c|}{ Irrigation Equipment } & \multirow{2}{*}{$\begin{array}{l}\text { Power } \\
\text { tiller } \\
\text { (nos.) }\end{array}$} & \multirow{2}{*}{$\begin{array}{l}\text { Tractor } \\
\text { (nos.) }\end{array}$} & \multirow{2}{*}{$\begin{array}{l}\text { Power } \\
\text { thresher } \\
\text { (nos.) }\end{array}$} & \multirow{2}{*}{$\begin{array}{l}\text { Corn } \\
\text { sheller } \\
\text { (nos.) }\end{array}$} & \multirow{2}{*}{$\begin{array}{l}\text { harvester/ } \\
\text { Reaper } \\
\text { (nos.) }\end{array}$} \\
\hline & & $\begin{array}{l}\text { DTW } \\
\text { (nos.) }\end{array}$ & $\begin{array}{l}\text { STW } \\
\text { (nos.) }\end{array}$ & $\begin{array}{l}\text { LLP } \\
\text { (nos.) }\end{array}$ & & & & & \\
\hline & Dabordanga & 1 & 8 & 0 & 7 & 1 & 1 & 0 & 1 \\
\hline & Shimultoli & 0 & 6 & 0 & 6 & 1 & 3 & 1 & 2 \\
\hline \multirow[t]{5}{*}{ Boda } & Majhgram & 1 & 10 & 1 & 7 & 0 & 1 & 0 & 0 \\
\hline & Shibaipara & 1 & 8 & 0 & 5 & 1 & 1 & 0 & 0 \\
\hline & Jamadarpara & 1 & 9 & 1 & 6 & 1 & 2 & 1 & 1 \\
\hline & Chandanbari & 2 & 10 & 1 & 5 & 1 & 2 & 1 & 1 \\
\hline & Bottali & 0 & 6 & 0 & 4 & 1 & 0 & 0 & 0 \\
\hline \multirow[t]{5}{*}{ Chandanbari } & Sarkarpara & 1 & 7 & 0 & 5 & 1 & 1 & 1 & 0 \\
\hline & Jorpakuri & 0 & 8 & 0 & 6 & 0 & 1 & 0 & 0 \\
\hline & Khansamapara & 1 & 6 & 1 & 6 & 0 & 2 & 0 & 0 \\
\hline & Arajigaighata & 1 & 8 & 1 & 6 & 1 & 2 & 1 & 1 \\
\hline & Horipur & 1 & 6 & 0 & 5 & 1 & 1 & 0 & 0 \\
\hline \multirow[t]{4}{*}{ Maidandighi } & Ragpur & 0 & 5 & 0 & 4 & 1 & 1 & 1 & 0 \\
\hline & Magurapara & 1 & 7 & 0 & 6 & 1 & 1 & 1 & 0 \\
\hline & Shipaipara & 0 & 5 & 0 & 4 & 0 & 0 & 0 & 0 \\
\hline & Total & 11 & 109 & 5 & 82 & 11 & 19 & 7 & 6 \\
\hline
\end{tabular}

DTW, STW, LLP and Power Tiller indicates 11 nos., 109 nos., 5 nos., and 82 nos. respectively.

\section{Status of agricultural mechanization in Debiganj Upazila}

From table 4 we can see the number of machineries used in different selected unions of Debiganj upazila. There are 4 combined harevester in this upazila. 


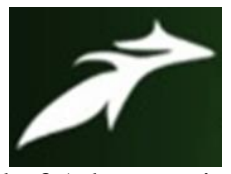

Milufarzana et al, International Journal of Advances in Agricultural Science and Technology,

Vol.8 Issue.9, September-2021, pg. 41-51

ISSN: $2348-1358$

Impact Factor: 6.057

NAAS Rating: 3.77

Table 4. Machinery used in different selected unions of Debiganj Upazila

\begin{tabular}{|c|c|c|c|c|c|c|c|c|c|}
\hline \multirow{2}{*}{$\begin{array}{l}\text { Name of } \\
\text { Unions }\end{array}$} & \multirow{2}{*}{$\begin{array}{l}\text { Name of } \\
\text { Villages }\end{array}$} & \multicolumn{3}{|c|}{ Irrigation Equipment } & \multirow{2}{*}{\begin{tabular}{|c|}
$\begin{array}{c}\text { Power } \\
\text { tiller }\end{array}$ \\
(nos.)
\end{tabular}} & \multirow{2}{*}{$\begin{array}{c}\text { Tractor } \\
\text { (nos.) } \\
\end{array}$} & \multirow{2}{*}{$\begin{array}{c}\begin{array}{c}\text { Power } \\
\text { thresher }\end{array} \\
\text { (nos.) }\end{array}$} & \multirow{2}{*}{$\begin{array}{c}\text { Corn } \\
\text { Sheller } \\
\\
(\text { nos.) }\end{array}$} & \multirow{2}{*}{$\begin{array}{c}\text { Reaper/ } \\
\text { Harvester } \\
\text { (nos.) }\end{array}$} \\
\hline & & $\begin{array}{l}\text { DTW } \\
\text { (nos.) }\end{array}$ & $\begin{array}{l}\text { STW } \\
\text { (nos.) }\end{array}$ & $\begin{array}{l}\text { LLP } \\
\text { (nos.) }\end{array}$ & & & & & \\
\hline & Prodhanpara & 1 & 5 & 0 & 3 & 1 & 1 & 0 & 0 \\
\hline & Moholdarpara & 0 & 6 & 0 & 5 & 2 & 1 & 1 & 1 \\
\hline \multirow[t]{5}{*}{ Debiganj } & Notunbandar & 1 & 5 & 0 & 6 & 3 & 2 & 1 & 0 \\
\hline & Taltola & 1 & 8 & 0 & 5 & 2 & 2 & 1 & 1 \\
\hline & Collagepara & 0 & 6 & 0 & 4 & 3 & 2 & 1 & 0 \\
\hline & Bondorpara & 0 & 5 & 0 & 3 & 1 & 0 & 1 & 0 \\
\hline & Mostofapur & 1 & 6 & 1 & 5 & 2 & 1 & 1 & 1 \\
\hline \multirow[t]{5}{*}{ Sonahar } & Clubganj & 1 & 6 & 0 & 4 & 2 & 1 & 1 & 0 \\
\hline & Dhontola & 1 & 10 & 0 & 5 & 1 & 2 & 0 & 0 \\
\hline & Mollikadah & 0 & 7 & 0 & 5 & 2 & 1 & 1 & 0 \\
\hline & Chaurangi Kalibari & 1 & 5 & 0 & 7 & 2 & 2 & 1 & 1 \\
\hline & Peralbari mistiripara & 1 & 8 & 0 & 5 & 1 & 1 & 1 & 0 \\
\hline \multirow[t]{4}{*}{ Debiduba } & Khutamar beltolipara & 2 & 10 & 1 & 3 & 2 & 0 & 0 & 0 \\
\hline & $\begin{array}{l}\text { Khutamar } \\
\text { Prodhanpara }\end{array}$ & 2 & 7 & 0 & 6 & 2 & 1 & 1 & 0 \\
\hline & Nalarpar & 1 & 5 & 0 & 4 & 3 & 0 & 0 & 0 \\
\hline & Total & 13 & 99 & 2 & 70 & 29 & 17 & 11 & 4 \\
\hline
\end{tabular}

DTW, STW, Power Tiller, Power Thresher and Corn Sheller indicates 13 nos., 99 nos., 70 nos.,

17 nos. and 11 nos. respectively.

\section{Status of agricultural mechanization in Panchagah district}

Figure 1 shows use of different machineries and it is evident that number of machines used are not same in three Upazilas. It is seen that use of irrigation equipment, power tiller and power thresher are comparatively more in Boda Upazila than Panchagarh sadar and Debiganj upazila. The figure self explains regarding number of machines used in different upazilas. 


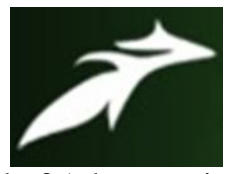

Milufarzana et al, International Journal of Advances in Agricultural Science and Technology,

Vol.8 Issue.9, September-2021, pg. 41-51

ISSN: $2348-1358$

Impact Factor: 6.057

NAAS Rating: 3.77

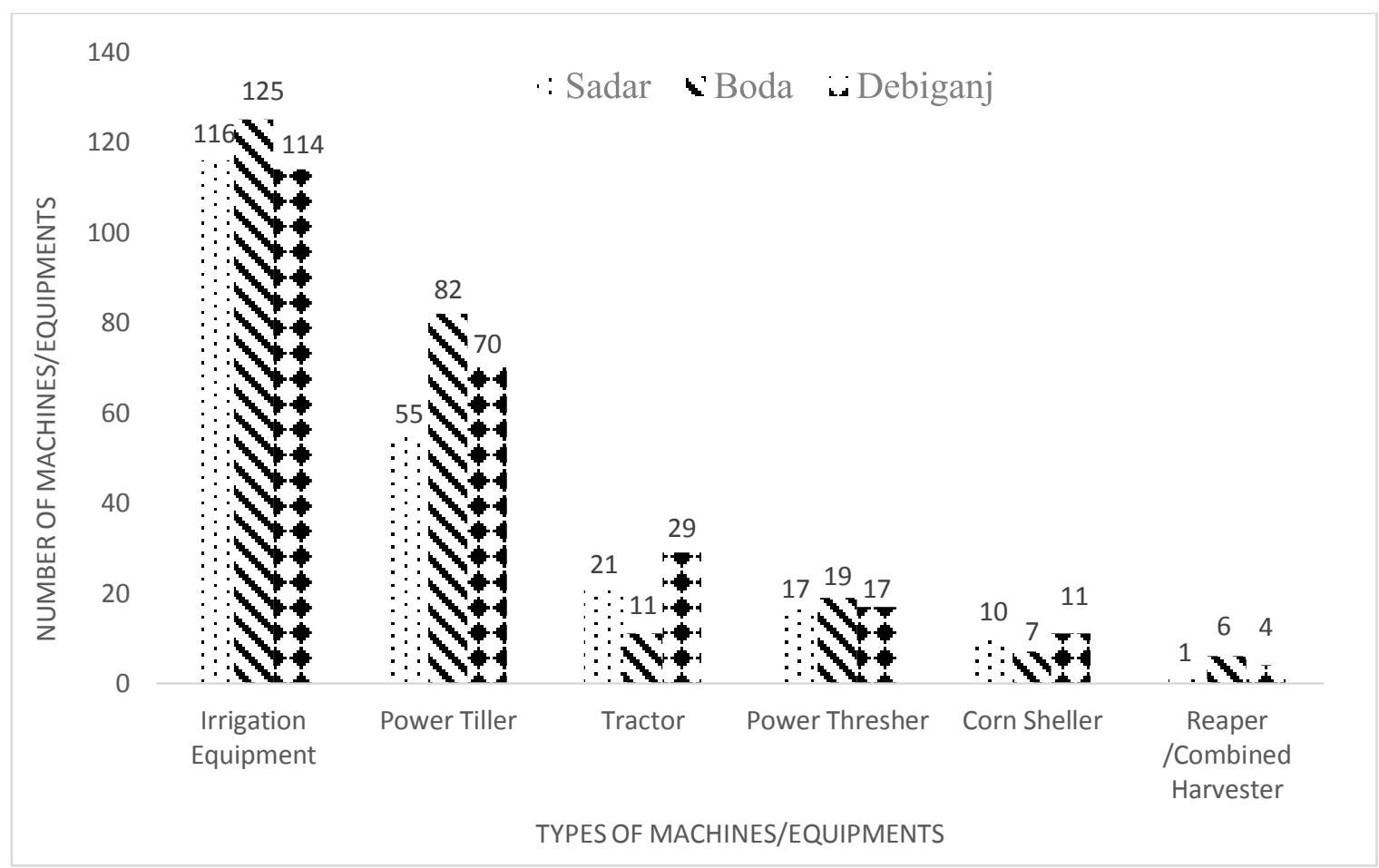

Figure 1. Comparison of different machines used in three selected upazilas of Panchagarh District.

\section{Conclusions}

A survey was conducted in 45 villages of 3 Upazilas of Panchagarh district to assess the present status of agricultural mechanization. Three unions from each upazila and 5 villages from each union was selected for the study. A survey questionnaire was used for the study.

The survey results revealed that there was enough power tillers (207) and tractors (61) for land preparation. Almost every farmer use sprayer. There was 33 DTW, 313 STW and 10 LLP for irrigation. But the matter of concern is very limited number of combine harvester or reaper (11). 


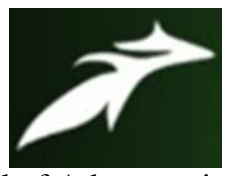

Milufarzana et al, International Journal of Advances in Agricultural Science and Technology,

Vol.8 Issue.9, September-2021, pg. 41-51

ISSN: $2348-1358$

Impact Factor: 6.057

NAAS Rating: 3.77

No rice transplanter was found in the study villages. It is a fact that mechanization is in progress

in these areas but need more extension work with modern machineries.

\section{References}

[1]. BBS (Bangladesh Bureau of Statistics).2017. Statistical Division, Ministry of Planning, People's Republic of Bangladesh, Dhaka, Bangladesh.

[2]. BBS (Bangladesh Bureau of Statistics). 2018. Statistical Yearbook of Bangladesh. Bangladesh Bur. Stat. Div., Mini. Plan. Govt. People's Republic of Bangladesh, Dhaka 38 ND edition. PP. 16, 78-86, 114-126, 139, 410, 421, 513.

[3]. BBS 2012. Agriculture crop cutting. Estimation of boro rice 2011-2012. 32 ND edition. Govt. People's Republic of Bangladesh.

[4]. BD Population census 2001, BD Bureau of cultural survey report of Panchagarh district.

[5]. Esmay, M. I. and Hall, C. W. 1972.Agricultural Mechanization in Developing Countries, Shin-Norinsha Co. Ltd.

[6]. IFPRI (International Food Policy Research Institute) 2012. The world food situation: new driving forces and required actions. December, Beijing, CGIAR Annual General Meeting.

[7]. MoA 2009. National Agriculture Policy. Ministry of Agriculture, Government of the People's Republic of Bangladesh, Shegun Bagicha, Dhaka-1000.

[8]. World Bank national accounts data and OECD National Accounts data files (2018-2019). Agriculture, forestry and fishing, value added (\% of GDP) - Bangladesh. 